\title{
Improvement of a duodenal leak: Two-way vacuum-assisted closure
}

\author{
๑ Seracettin Eğin, M.D., ๑ Berk Gökçek, M.D., ® Metin Yeşiltaş, M.D., \\ (1) Semih Hot, M.D., 들 Dursun Özgür Karakaş, M.D.
}

Department of General Surgery, Health Sciences University, Okmeydanı Training and Research Hospital, İstanbul-Turkey

\begin{abstract}
A 55-year-old male patient developed a duodenal re-leak, which caused severe peritonitis, on the second postoperative day after surgery to treat an acutely perforated duodenal ulcer. Relaparotomy was performed 2 days after surgery for the re-leak after omentoplasty. The necrotic omentum was dissociated from the bulbus duodeni.Viable omentum for reinsertion of the omental patch was not found. The turned-outward duodenal mucosa was excised and the duodenal perforation was sutured. Two-way vacuum-assisted closure (VAC) was carried out by taking a liquid culture of the abdomen and washing the abdomen. The two-way VAC exchange procedures were continued every 3 days until the re-leak was terminated. The whole treatment process occurred in the intensive care unit. The duodenal leak was completely stopped by $4 \mathrm{I}$ days after surgery. The subcutaneous layer was dissected from the fascial layer of the anterior wall of the abdomen; thus, the abdominal skin was closed without tension and the patient was subsequently discharged. In conclusion, since primary source control is often difficult when treating duodenal leaks, the two-way VAC system is a convenient solution for localizing the source of the peritonitis and removing toxic peritoneal material.
\end{abstract}

Keywords: Duodenal leak following omentoplasty; duodenal ulcer perforation; vacuum-assisted closure.

\section{INTRODUCTION}

Re-leak following omentoplasty for acute duodenal ulcer perforation is a well-known clinical issue with a high mortality rate. The incidence of re-leak following omentoplasty ranges between 4 and $16 \%$ in various studies. ${ }^{[1-3]}$ Kumar et al. ${ }^{[4]}$ cited the following risk factors for re-leak after surgical closure of a perforated duodenal ulcer by Graham's Patch: age $>60$ years, pulse rate $>110 /$ minute, blood pressure $<90$ $\mathrm{mmHg}$, hemoglobin $<10 \mathrm{~g} / \mathrm{dL}$, serum albumin $<2.5 \mathrm{~g} / \mathrm{dL}$, total lymphocyte count $<1800$ cells $/ \mathrm{mm}^{3}$, and perforation size $>5$ $\mathrm{mm}$. The size of the peptic duodenal ulcer and the serum albumin and hemoglobin levels were independent risk factors in a multivariate analysis.

The presently described case had severe peritonitis due to re-leak after a Roscoe-Graham operation for an acute per- forated duodenal ulcer, which was managed by implementing two-way VAC.

\section{CASE REPORT}

The patient, a fifty-five-year-old male, had severe and diffuse abdominal pain, loss of appetite, nausea, and vomiting for the previous 24 hours. Abdominal rigidity and rebound was determined in the physical examination, and subdiaphragmatic free air was seen in a plain x-ray. In the preoperative stage, the pulse rate was 120 beats/minute, blood pressure was $80 / 40 \mathrm{mmHg}$, hemoglobin was $17.3 \mathrm{~g} / \mathrm{dL}$, total lymphocyte count was 880 cells $/ \mathrm{mm}^{3}$, and serum albumin was $2.1 \mathrm{~g} / \mathrm{dL}$. The patient was operated on using the Roscoe-Graham technique for acute duodenal ulcer perforation. The size of the perforation on the front wall of the bulbus duodeni was 10 $\mathrm{mm}$. Re-leak following omentoplasty was diagnosed 2 days

Cite this article as: Eğin S, Gökçek B, Yeşiltaş M, Hot S, Karakaş DÖ. Improvement of a duodenal leak: Two-way vacuum-assisted closure. Ulus Travma Acil Cerrahi Derg 2019;25:89-92.

Address for correspondence: Seracettin Eğin, M.D.

SBÜ Okmeydanı Eğitim ve Araştırma Hastanesi, Genel Cerrahi Kliniği, İstanbul, Turkey.

Tel: +90 212 - 3145555 E-mail: seracettin_egin@hotmail.com 
after surgery as soon as the tube drainage was observed to have bilious content and relaparotomy was performed immediately (Fig. Ia). Abundant bile fluid was detected in the abdomen. Necrotic omentum was dissociated from the bulbus duodeni and viable omentum for reinsertion of an omental patch was not found. The duodenal mucosa had turned outward. After taking the sample for culture, the bile fluid was aspirated, and the peritoneal cavity was irrigated with 12 liters of warm sterile saline. The turned-outward duodenal mucosa was excised, and the duodenal perforation was closed by suturing with a $2 / 0$ vicryl. At the time of re-suturing, a two-way VAC management system was applied because of the increased risk of continuous re-leak in the following period (ABThera Open Abdomen Management System; Kinetic Concepts Inc./Acelity, L.P. Inc., San Antonio, TX, USA). One of the additional sponge extensions was extracted from the management system with six additional sponge extensions. One tip of the extracted additional sponge extension was placed next to the duodenal perforation and the other tip was taken out of the upper-right quadrant. Five additional sponge extensions were carried out in the abdominal cav- ity. The two sets of sponge extensions were separately connected to 2 vacuum devices with $75 \mathrm{mmHg}$ of pressure. The external appearance of the first VAC application can be seen in Figure Ib. Total parenteral nutrition was initiated for the patient's feeding and sustained until the abdomen was closed. Nasogastric tube application was also continued until definitive abdomen closure. The two-way VAC procedures were carried out at 3-day intervals and included taking a liquid culture from the abdomen and washing the abdomen. It was constantly observed that the leak from the sutured duodenal perforation continued during the two-way VAC change applications. Acinetobacter baumannii was observed in the liquid culture of the abdomen, and therefore the patient was treated with meropenem and tazobactam. All treatment processes were sustained in the intensive care unit after VAC exchange applications. Forty days after surgery, no more bile leaked into the VAC liquid collection canister and only serous fluid was seen. Abdominal computerized tomography (CT) with double contrast (oral and intravenous) was performed in the same day. No contrast leak was detected by abdominal $\mathrm{CT}$; therefore, we concluded that the abdominal was defini-
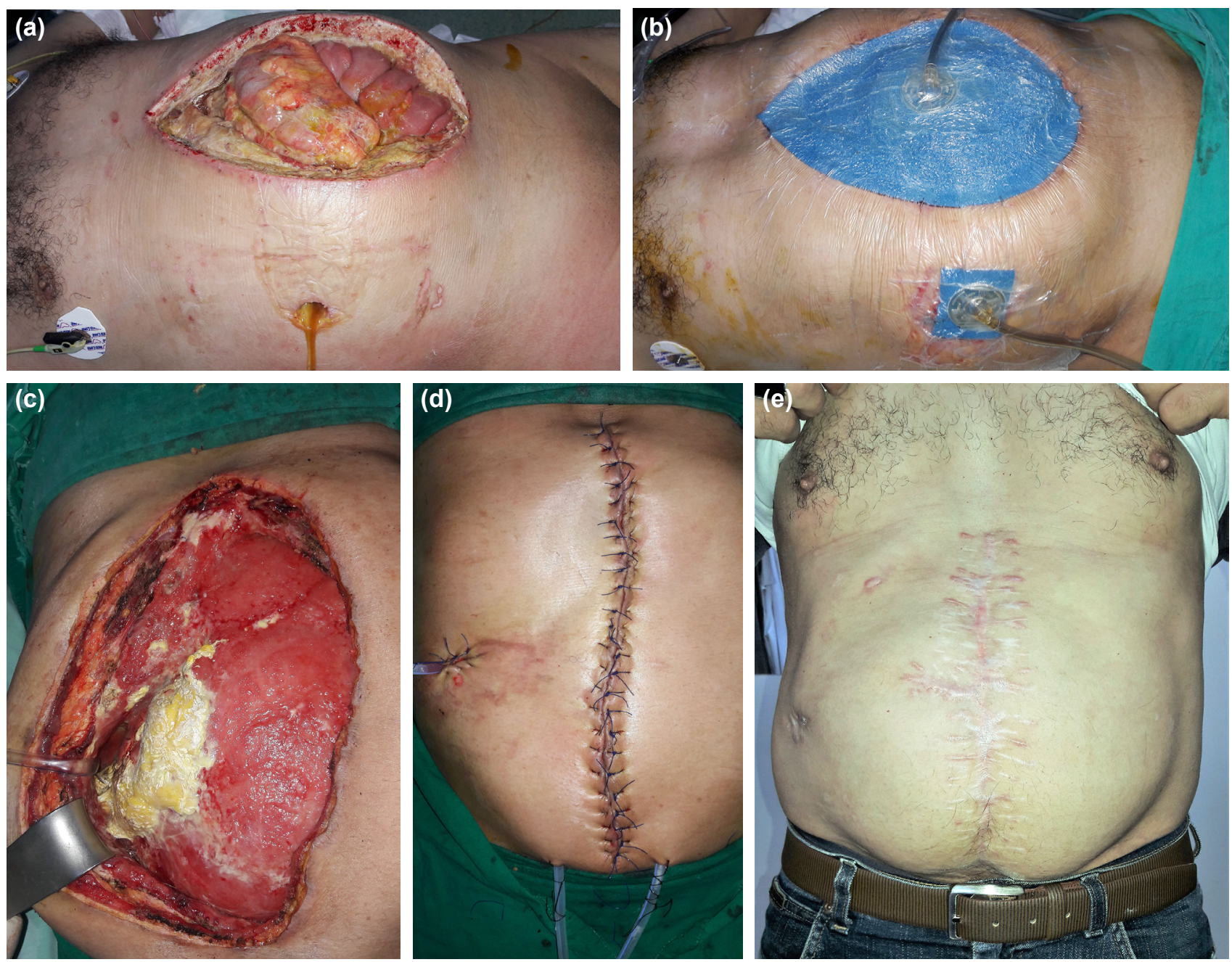

Figure 1. (a) Peritonitis due to duodenal leak following omentoplasty. (b) The external appearance of the two-way vacuum-assisted closure technique. (c) No bile leakage is present, and the inside of the abdomen is completely clean. (d) The abdominal skin was closed after dissecting the subcutaneous layer from the fascial layer of the abdomen. (e) External image of the abdomen six months after discharge. 
tively sealed. The next day, it was observed that the duodenal leak was completely stopped. Figure Ic shows that no bile leakage was present, and the inside of the abdomen was completely clean. The subcutaneous layer was dissected from the fascial layer of the anterior wall of the abdomen. Thus, the OA was closed by skin without tension (Fig. Id) and the patient was discharged. The external image of the abdomen six months after discharge is shown in Figure le.

\section{DISCUSSION}

Until today, various studies have recommended multiple surgical and conservative methods for the management of re-leak following omentoplasty. Maghsoudi and Ghaffari suggested sub-hepatic drainage and re-insertion of the omental patch, only sub-hepatic drainage, and a jejunal serosal patch. ${ }^{[3]}$ Saurabh et al. ${ }^{[5]}$ recommended cholecystoduodenoplasty, a jejunal patch, triple-tube-ostomy, T-tube duodenostomy, and conservative methods. The incidence of mortality in these two studies was $5 / 17(29.4 \%)$ and $32 / 4$ I $(78 \%)$, respectively. The rate of success in stopping the leak was observed as high $(12 / 17,70.6 \%)$ in the first study but rather low $(9 / 41,22 \%)$ in the second study. ${ }^{[3,5]}$ The second study stated that 26 of 32 mortality patients died due to sepsis. ${ }^{[5]}$ In severe abdominal sepsis, the open abdomen (OA) may allow control of any persistent source of infection and the effective removal of infected or cytokine-loaded peritoneal fluid. Vacuum-assisted closure (VAC) techniques have a history of safety as the most extensively used methods for temporary abdominal wall closure. ${ }^{[6]}$ In cases with a persistent source of peritonitis (unsuccessful source control), the $O A$ is an option for emergency surgery patients with severe peritonitis and severe sepsis or septic shock (grade of recommendation $2 \mathrm{C}$ ). ${ }^{\left[{ }^{[]}\right.}$

The additional surgical procedures recommended in various studies for the management of re-leak following omentoplasty are not always successful. These surgical procedures have very low success rates. The sutures that enter into the abdomen are contaminated by the bile leak and therefore are not safe. Infected and edematous tissues are usually cut by the applied suture. All types of anastomosis in the contaminated abdomen may be resulted in failure. Additional surgical procedures in patients with severe peritonitis always increase the risks of morbidity and mortality. It is not always possible to control the primary source in patients with duodenal leakage; in these patients, it is necessary to localize the duodenal leakage completely. The two-way VAC system is well-suited to localize the duodenal leakage completely and discharge the toxic liquids that accumulate in the abdomen. In addition, the VAC system accelerates the formation of granulation tissue; for this reason, the duodenal perforation closes early with the granulation tissue. The reason for applying the low pressure of $75 \mathrm{mmHg}$ is to avoid increasing the duodenal leakage with an excessive negative pressure effect. This patient was our first case using the two-way VAC system for re-leak management following omentoplasty due to an acute duodenal ulcer perforation. This strategy was also successfully carried out in three cases with anastomotic leak following upper gastrointestinal system surgery and esophagojejunostomy; the first of these three cases was previously reported. ${ }^{[8]}$ The twoway VAC technique should encourage surgeons to remedy both a re-leak following Roscoe-Graham omentoplasty and an anastomotic leak following upper gastrointestinal system surgery.

The three separate additional surgical techniques applied by Maghsoudi and Ghaffari also included continuous intra-abdominal irrigation and long-term hospitalization ${ }^{[3]}$ and, overall, had a $70.6 \%$ success rate. The number of re-leak cases following omentoplasty (I7 patients) was low, particularly when considering the study performed by Saurabh et al. ${ }^{[3,5]}$ The additional surgical procedures performed in two studies were dissimilar except for the jejunal patch. The numbers of patients treated using the jejunal patch technique were $1 / 17$ and $7 / 4 \mathrm{I}$ in the first and second studies, respectively. In the second study, the mortality rate increased as the variety and number of additional surgical procedures was augmented. In the second study, 13 patients treated conservatively died. In both first and second study, it was thought that primary source control was not sufficiently provided in mortal patients. The most common cause of mortality in these studies was sepsis. ${ }^{[3,5]}$

In conclusion, since primary source control is often difficult when treating duodenal re-leaks, the two-way VAC technique is a convenient solution for localizing the peritonitis source and removing toxic peritoneal material. Moreover, intraabdominal sepsis in duodenal re-leaks may be treated without additional surgical procedures via the two-way VAC technique.

Conflict of interest: None declared.

\section{REFERENCES}

1. Chalya PL, Mabula JB, Koy M, Mchembe MD, Jaka HM, Kabangila R, et al. Clinical profile and outcome of surgical treatment of perforated peptic ulcers in Northwestern Tanzania: A tertiary hospital experience. World J Emerg Surg 2011;6:31. [CrossRef]

2. Gupta S, Kaushik R, Sharma R, Attri A. The management of large perforations of duodenal ulcers. BMC Surg 2005;5:15. [CrossRef]

3. Maghsoudi H1, Ghaffari A. Generalized peritonitis requiring re-operation after leakage of omental patch repair of perforated peptic ulcer. Saudi J Gastroenterol 2011;17:124-8. [CrossRef]

4. Kumar K, Pai D, Srinivasan K, Jagdish S, Ananthakrishnan N. Factors contributing to releak after surgical closure of perforated duodenal ulcer by Graham's Patch. Trop Gastroenterol 2002;23:190-2.

5. Saurabh S. Sanjanwala, Vinaykumar N. Thati1, Omprakash S. Rohondia, Samir U. Rambhia. Comparison of operative procedures for re-leaks duodenal perforation: a cross-sectional analysis from a tertiary care hospital in a developing country. Int Surg J 2016;3:1314-7. [CrossRef]

6. Sartelli M, Abu-Zidan FM, Ansaloni L, Bala M, Beltrán MA, Biffl WL, et al. The role of the open abdomen procedure in managing severe $a b$ dominal sepsis: WSES position paper. World J Emerg Surg 2015;10:35. 
7. Coccolini F, Roberts D, Ansaloni L, Ivatury R, Gamberini E, Kluger Y, et al. The open abdomen in trauma and non-trauma patients: WSES guidelines. World J Emerg Surg 2018;13:7. [CrossRef]
8. Eğin S, Alemdar A, Sağlam F, Güney B, Güven H. Treatment with vacuum-assisted closure system: A case of anastomotic leak after upper gastrointestinal surgery. Ulus Travma Acil Cerrahi Derg 2018;24:601-3.

\section{OLGU SUNUMU - ÖZET}

\section{Duodenal kaçağın iyileştirilmesi: İki yönlü vakum yardımlı kapama \\ Dr. Seracettin Eğin, Dr. Berk Gökçek, Dr. Metin Yeşiltaş, Dr. Semih Hot, Dr. Dursun Özgür Karakaş}

Sağlık Bilimleri Üniversitesi, Okmeydanı Eğitim ve Araştırma Hastanesi, Genel Cerrahi Kliniği, İstanbul

Elli beş yaşında erkek hastada, perfore duodenal ülserin tedavisi için yapılan ameliyattan sonraki ikinci günde ciddi peritonite neden olan duodenal kaçak gelişti. Omentoplasti sonrası tekrar sızıntı nedeniyle ameliyattan iki gün sonra relaparotomi yapıldı. Nekrotik omentum, bulbus duodeniden ayrılmıştı. Omental yamanın yeniden yerleştirilmesi için canlı omentum bulunamadı. Dışa dönmüş duodenum mukozası kesildi ve duodenum perforasyonu dikildi. İki yönlü vakum yardımlı kapama (VYK), karın sıvı kültürü alınarak ve karın yıkanarak yapıldı. İki yönlü VYK değişim işlemleri, sızıntı sonlandırılana kadar her üç günde bir sürdürüldü. Tüm tedavi süreci yoğun bakımda gerçekleşti. Duodenal sızıntı ameliyattan 4 I gün sonra tamamen durdu. Cilt altı tabakası karın ön duvarının fasiyal tabakasından ayrıştırıldı; böylece, karın cildi gergin olmadan kapatılı ve hasta daha sonra taburcu edildi. Sonuç olarak, primer kaynak kontrolü duodenal sızıntıları tedavi ederken sıklıkla zor olduğu için, iki yönlü VYK sistemi, peritonit kaynağını lokalize etmek ve toksik peritoneal materyali uzaklaştırmak için uygun bir çözümdür.

Anahtar sözcükler: Duodenal ülser perforasyonu; omentoplasti sonrası duodenal kaçak; vakum yardımlı kapama.

Ulus Travma Acil Cerrahi Derg 2019;25(I):89-92 doi: 10.5505/tjtes.20I8.22934 